\title{
Pendidikan Kesehatan tentang Hipertensi dan Perawatannya pada Anggota PKK RT 01 RW 06 Pedurungan Tengah Semarang
}

\author{
Maria Agustina Ermi ${ }^{1}$, Tri Sulistiyowati ${ }^{2 *}$, Raimonda Amayu Ida Vitani ${ }^{3}$, Dian \\ Puspitasari $^{4}$, Florentina Niken Widyastuti ${ }^{5}$ \\ STIKes St.Elisabeth Semarang, Jl. Kawi Raya No.11, Wonotingal, Kec. Candisari, Kota Semarang, \\ Jawa Tengah $50232^{1,2,3,4,5}$ \\ Email: ermi.trisulistiyowati@gmail.com ${ }^{2 *}$
}

\begin{abstract}
ABSTRAK
Hipertensi merupakan suatu penyakit yang banyak dijumpai dan sangat sering menyebabkan serangan jantung yang mematikan. Penyakit ini menempati urutan pertama penyebab kematian di seluruh dunia, termasuk di Indonesia. Hipertensi merupakan silent killer sehingga pengobatannya sering terlambat. Hipertensi dan komplikasinya dapat dicegah dengan menerapkan pola hidup sehat. Pendidikan kesehatan dilaksanakan kepada anggota PKK RT 01 RW 06 Pedurungan Tengah dengan memberikan materi tentang hipertensi dan perawatannya. Setelah pemberian materi dan diskusi, dilanjutkan dengan pemeriksaan tekanan darah. Peserta antusias mengikuti penyuluhan dari awal sampai akhir. Dari hasil evaluasi dengan memberikan pertanyaan terkait materi yang diberikan, mereka dapat menyebutkan kembali pengertian, penyebab, tanda gejala, pencegahan serta perawatan hipertensi dengan benar. Dampak dari kegiatan pendidikan kesehatan ini adalah meningkatnya pengetahuan anggota PKK RT 01 RW 06 Pedurungan Tengah tentang hipertensi dan perawatannya.
\end{abstract}

Kata kunci: Hipertensi; Perawatan; Anggota PKK

\section{ABSTRACT}

Hypertension is a disease that is common and very often causes deadly heart attacks. This disease ranks as the first cause of death worldwide, including in Indonesia. Hypertension is a silent killer, so treatment is often late. Hypertension and its complications can be prevented by adopting a healthy lifestyle. Health education is carried out to members of the PKK RT 01 RW 06 Pedurungan Tengah by providing material about hypertension and its treatment. After providing material and discussion, it was followed by blood pressure checks. Participants were enthusiastic about attending the counseling from beginning to end. From the results of the evaluation by asking questions related to the material given, they can recite the meaning, causes, symptoms, prevention and treatment of hypertension correctly. The impact of this health education activity is to increase the knowledge of PKK RT 01 RW 06 Pedurungan Tengah members about hypertension and its treatment.

Keywords: Hypertension; Care; PKK Members

\section{PENDAHULUAN}

Hipertensi merupakan masalah kesehatan yang sering ditemukan ditengah masyarakat dan mengakibatkan angka kesakitan yang tinggi. Sampai saat ini, hipertensi masih merupakan tantangan besar di Indonesia. Penyakit ini dapat memicu penyakit lain seperti stroke, penyakit jantung koroner, gagal jantung, dan penyakit ginjal, sehingga perlu 
dilakukan pencegahan dan penanganan sebelum komplikasi dan akibat buruk lainnya terjadi. Laki-laki dan perempuan sama-sama memiliki resiko hipertensi. Laki-laki lebih beresiko mengalami hipertensi dibandingkan perempuan pada saat usia $<45$ tahun, tetapi pada saat usia > 65 tahun, perempuan lebih beresiko mengalami hipertensi (Taslim dan Betris, 2020; Prasetyaningrum, 2014).

Munculnya masalah kesehatan tidak hanya disebabkan oleh kelalaian individu, namun dapat pula disebabkan oleh ketidaktahuan masyarakat sebagai akibat dari kurangnya informasi yang benar mengenai suatu penyakit (Rahmadiana, 2012). Hipertensi dapat dicegah dengan meningkatkan pengetahuan masyakarat tentang hipertensi melalui pendidikan kesehatan kepada masyarakat (Hairil, 2020; Nuraini dkk, 2018)

Berdasarkan hasil survei pada ibu - ibu anggota PKK di RT 01 RW 06 Pedurungan Tengah terdapat warga yang menderita hipertensi, namun belum mengetahui cara pencegahan dan perawatannya. Oleh karena itu, kami melakukan pendidikan kesehatan tentang hipertensi dan perawatannya untuk meningkatkan pengetahuan masyarakat dan mencegah terjadi hipertensi dan komplikasinya.

\section{METODE}

Kegiatan pengabdian masyarakat dilaksanakkan pada saat pertemuan PKK di salah satu rumah warga di RT 01 RW 06 Pedurungan Tengah Semarang. Kegiatan pengabdian masyarakat dilaksanakan pada tanggal 5 Agustus 2012 diikuti oleh 35 orang peserta Metode pelaksanaan pengabdian masyarakat dilakukan dengan pendidikan kesehatan tentang hipertensi dan perawatannya yang meliputi: pengertian dan klasifikasi hipertensi, penyebab, tanda gejala dan pencegahan serta perawatan hipertensi. Setelah pendidikan kesehatan kemudian dilanjutkan dengan pengukuran tekanan darah.

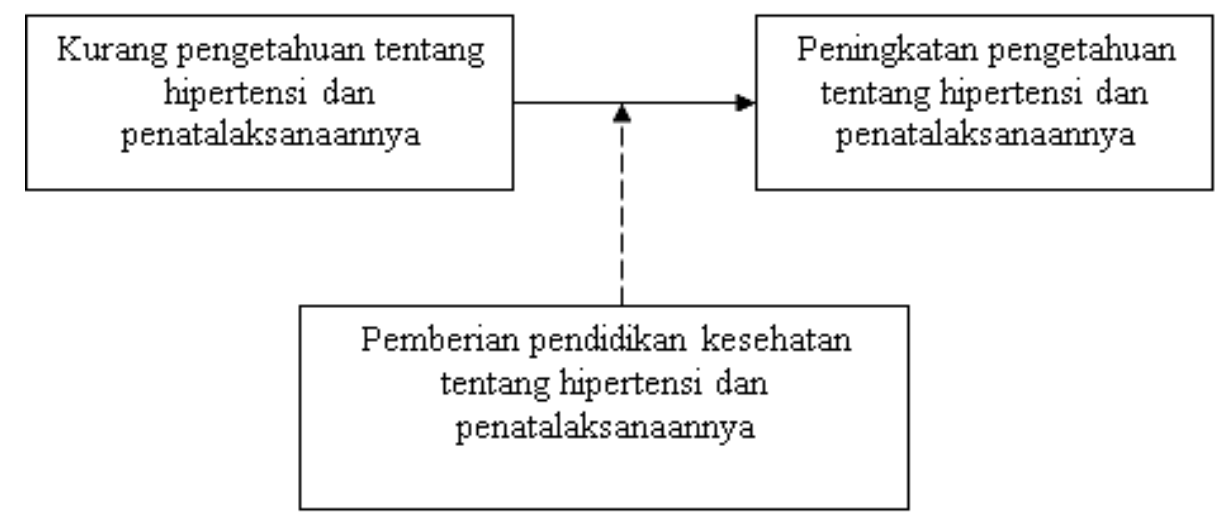

Gambar 1. Kerangka Kegiatan Pengabdian Masyarakat 
Mekanisme pelaksanaan kegiatan dilakukan dengan 4 (empat) tahapan, yaitu: perencanaan, tindakan, observasi dan evaluasi, serta refleksi. Kegiatan-kegiatan dari masing-masing tahapan adalah sebagai berikut:

\section{Perencanaan}

Kegiatan-kegiatan yang dilakukan pada tahap perencanaan adalah:

a. Mengajukan perizinan pada ketua RT 01 RW 06 Pedurungan Tengah

b. Pembentukan tim pelaksanaan PKM

c. Melakukan kontrak waktu pelaksanaan dengan ketua PKK RT 01 RW 06 Pedurungan Tengah

2. Tindakan

Tindakan dalam kegiatan ini berupa implementasi program, yaitu:

a. Memberikan pendidikan kesehatan tentang hipertensi dan perawatannya yang meliputi: pengertian dan klasifikasi hipertensi, penyebab, tanda gejala dan pencegahan serta perawatan hipertensi.

b. Melakukan pengukuran tekanan darah.

3. Observasi dan evaluasi

Observasi dilakukan selama proses pendidikan kesehatan berlangsung. Beberapa hal yang diobservasi adalah minat, keseriusan dan sikap ingin tahu tentang hipertensi dan perawatannya

4. Refleksi

Refleksi dilakukan terhadap kegiatan yang telah dilaksanakan. Hal ini dilakukan untuk mengetahui kekurangan atau kelebihan terhadap kegiatan yang telah dilakukan dalam rangka menetapkan rekomendasi terhadap keberlangsungan atau pengembangan kegiatan berikutnya

\section{HASIL, PEMBAHASAN, DAN DAMPAK}

Hasil pengabdian masyarakat menunjukkan adanya peningkatan pengetahuan peserta tentang hipertensi dan perawatannya. Hal ini dapat dilihat dari hasil evaluasi, di mana peserta dapat menyebutkan kembali tentang pengertian, penyebab, tanda gejala, pencegahan dan perawatan hipertensi dengan benar. 

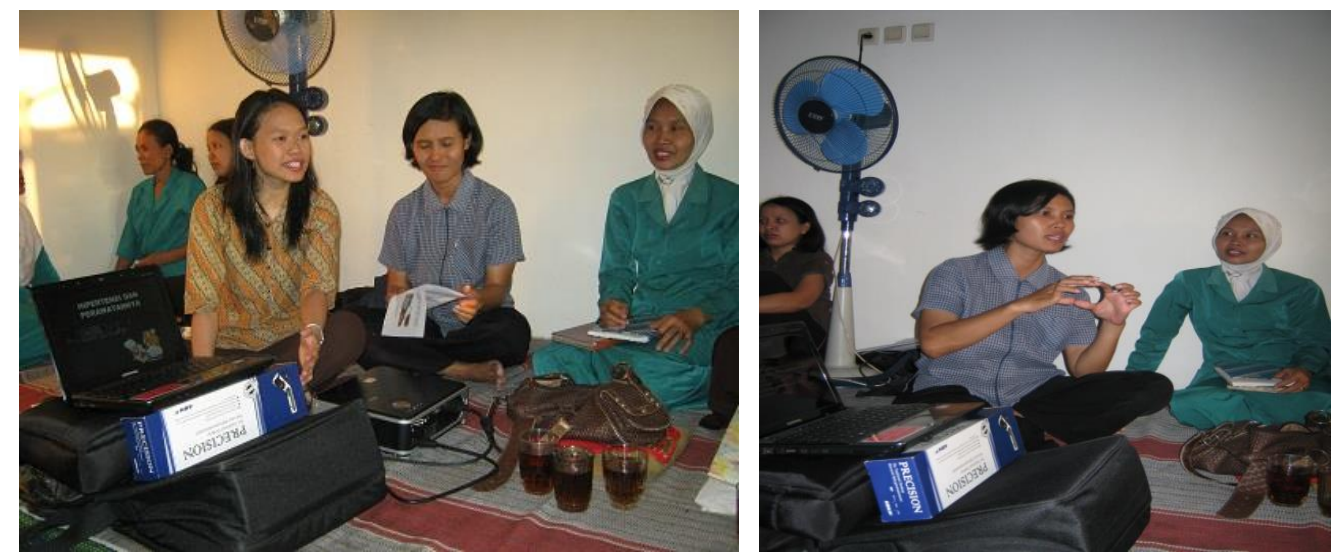

Gambar 2. Pemberian pendidikan kesehatan tentang hipertensi dan perawatannya

Pada saat diberikan pendidikan kesehatan, masyarakat memperhatikan dan aktif bertanya tentang hipertensi dan perawatannya.
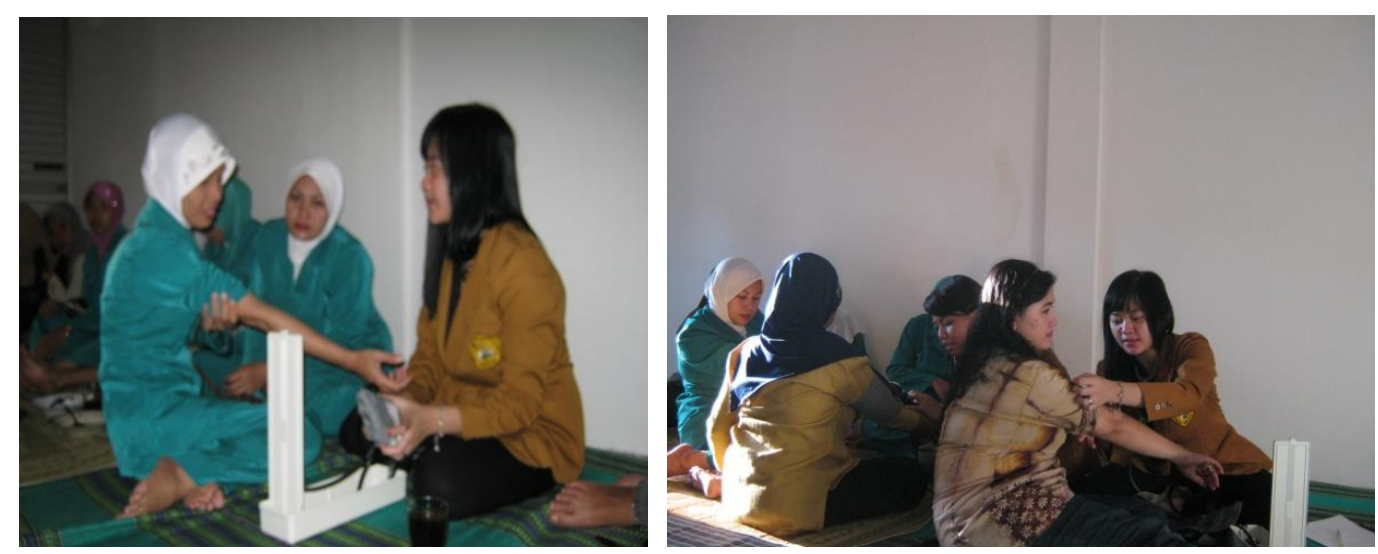

Gambar 3. Pengukuran tekanan darah pada anggota PKK RT 01 Rw 06 Pedurungan Tengah

Setelah diberikan pendidikan kesehatan, tim pengabdian masyarakat melakukan pengukuran tekanan darah. Dari hasil pengukuran tekanan darah terdapat 5 orang yang mengalami peningkatan tekanan darah.

Hipertensi sebagai salah satu penyakit yang saat ini masih menjadi masalah kesehatan di masyarakat dapat dilakukan penceghan dengan meningkatkan pengetahuan masyakarat dan melakukan deteksi dini adanya peningkatan tekanan darah. Pengetahuan yang meningkat diharapkan dapat meningkatkan kemampuan masyarakat dalam melakukan tindakan pencegahan dan perawatan hipertensi. Pengetahuan dapat menjadikan seseorang memiliki kesadaran sehingga akan berperilaku sesuai dengan pengetahuan yang dimiliki. Perubahan perilaku yang dilandasi pengetahuan, kesadaran dan sikap yang positif bersifat langgeng karena didasari oleh kesadaran mereka sendiri bukan paksaan (Notoatmojo, 2011) 
Beberapa tindakan perawatan mandiri yang dapat dilakuan pada pasien hipertensi adalah mengatur pola diet, latihan jasmani, berhenti merokok dan minum alkohol, mempertahankan berat badan dalam rentang normal, mengatasi stress, melakukan pemeriksaan tekanan darah secara berkala dan mengkonsumsi obat penurun tekanan darah secara teratur harus sesuai saran dokter (Made, 2020).

Dari hasil evaluasi didapatkan hasil : peserta memperhatikan dan aktif mengikuti kegiatan dari awal hingga akhir. Peserta memiliki rasa ingin tahu tentang hipertensi dan perawatannya. Terdapat 6 orang peserta yang mengajukan pertanyaan tentang gejala hipertensi, cara mengatasi hipertensi di rumah dan penggunaan terapi herbal untuk menurunkan tekanan darah.

Dampak dari kegiatan ini adalah peningkatan pengetahuan anggota PKK RT 01 RW 06 Pedurungan Tengah tentang hipertensi dan penatalaksanaannya. Sebelum diberikan pendidikan kesehatan, anggota PKK belum mengetahui tentang hipertensi dan perawatannya. Setelah diberikan pendidikan kesehatan mereka dapat menyebutkan kembali pengertian, penyebab, tanda gejala, pencegahan dan perawatan hipertensi.

\section{SIMPULAN}

Kegiatan pengabdian masyarakat yang dilaksanakan pada anggota PKK RT 01 RW 06 pedurungan Tengah Semarang. Setelah diberikan pendidikan kesehatan, tingkat pengetahuan anggota PKK RT 01 RW 06 Pedurungan Tengah tentang hipertensi dan penatalaksanaannya meningkat. Setelah diberikan pendidikan kesehatan mereka dapat menyebutkan kembali pengertian, penyebab, tanda gejala, pencegahandan perawatan hipertensi. Dari hasil pengukuran tekanan darah terdapat 5 orang yang mengalami peningkatan tekanan darah.

\section{UCAPAN TERIMAKASIH}

Terima kasih kami ucapkan kepada STIKes St. Elisabeth Semarang dan ketua PKK RT 01 RW 06 Pedurungan Tengah yang telah memberikan kesempatan dan dukungan dalam pelaksanaan pengabdian masyarakat.

\section{DAFTAR PUSTAKA}

Budi, Muhmmad, Agus, dkk. (2015). Hipertensi Manajemen Komprehensif. Surabaya: Airlangga University Press. 
Hairil. (2020). Edukasi Upaya Penceghaan Hipertensi pada Masyarakat di Kecamatan Passi Barat Kabupaten Bolaang Mongondow. JPKMI. 1(3), 154-160. http://dx.doi.org/10.36596/jpkmi.v1i3.61

Ni Made Dwi, Made Mahaguna. (2020). Buku Ajar Keperawatan Medikal Bedah I. Jawa Tengah: Lakeisha

Notoatmodjo. (2011). Kesehatan Masyarakat. Jakarta: Rineka Cipta

Nuraeni, A., Mirwanti, R., \& Anna, A. (2018). Upaya Pencegahan dan Perawatan Hipertensi di Rumah Melalui Media Pembelajaran Bagi Masyarakat di Kabupaten Pangandaran. Jurnal Bagimu Negeri, 2 (1), 174-178. https://doi.org/10.26638/jbn.554.8651

Prasetyaningrum. (2014). Hipertensi Bukan Untuk Ditakuti.Jakarta: Fmedia Imprint Agro Media Pustaka.

Taslim, T., \& Betris, Y. (2020). Gambaran Pemberian Obat pada Penderita Hipertensi di Puskesmas Rawang. Jurnal Riset Kefarmasian Indonesia, 2(2), 72-79. https://doi.org/10.33759/jrki.v2i2.81 